\title{
Grow Me Please Model and Academic Supervisory Performance
}

\author{
Dedy Achmad Kurniady, Aan Komariah*
}

Educational Administration Programs, School of Postgraduate Studies, Universitas Pendidikan Indonesia (UPI), Indonesia

Copyright $\mathrm{C} 2019$ by authors, all rights reserved. Authors agree that this article remains permanently open access under the terms of the Creative Commons Attribution License 4.0 International License

\begin{abstract}
This study applied the "grow me" academic supervision model, with the modification of "please" as a technical strategy of operation that combines the implementation of academic supervision activities carried out by headmasters to improve the teacher professional development activities. The research method used was a design-based research (DBR) which built a stronger relationship between education research and real-world problems of the academic supervision practices in two batches of headmaster training and education program as many as 80 people in the two batches of 2018. The results of the study showed that the "grow me please" model had provided operational guidance to the headmasters in conducting academic supervision for the continuous professional development of professional teachers. The conclusion of this study was that the "grow me please" model could be used as a technique for the headmasters to implement the academic supervision of in carrying out continuous teacher professional development assistance.
\end{abstract}

Keywords Academic Supervision, Continuous Professional Development, Grow Me Please Model

\section{Introduction}

One of the most strategic competencies of headmasters to improve teachers' professionalism is supervision. As the main competencies of the three competencies of headmasters in addition to managerial and entrepreneurship, supervision is seen as having a direct and strategic role in fostering the teaching profession both in learning and development of the teachers' career. However, some research findings on the competency of supervision still have not shown encouraging results because of different understanding of the goals and functions of the academic supervision program, poor understanding in the preparation of the academic supervision programs, lack of skills in the approach or technique for implementing academic supervision, difficulty committing to follow-up the academic supervision program, and lack of coordination between the headmasters and supervisors in the academic supervision program (preliminary survey, Komariah $^{1}$ ). That field findings indicate that there is an obstacle to the implementation of academic supervision carried out by the headmasters to the teachers. One of the obstacles is caused by the level of competency of the headmaster's supervision that has not been optimal yet, especially in supervision techniques/methods. Supervision competency still occupies the lowest position among other competencies. $^{2}$

Supervision competency is an aspect whose role is closely related to the existence as a leader. Through supervision, the headmasters can give influence, provide guidance and direct their guidance to the teachers so that they can achieve the task of developing their profession properly. The touch of supervision ignites the enthusiasm of the teachers to improve their performance and the varied and consistent activities can maintain their spirit. This is a significant contribution from the headmasters in improving the quality of education in schools. ${ }^{3-6}$

Awareness to conduct the academic supervision has not been followed by consistency in the implementation of the program, for example, observing the class by applying various instruments in accordance to the learning objectives and conducting follow-up as the findings of class visits. The execution of the supervision program is still limited to the formalities of the implementation of teacher performance assessments for their career advancement which must be done legally once a year to get the teacher performance score. The headmasters conduct classroom observations with using performance assessment instruments that have been set for the purpose of obtaining performance scores whether they get a very good, good, moderate, sufficient or less score than the results of the teacher performance. As part of the headmaster's performance standards, academic supervision must be carried out as a planned program with the right techniques and carried out consistently and 
consequently to get enjoyable learning and in accordance with the activities of professional teachers. ${ }^{78}$

The obligation to assess teacher performance is a trigger for regular academic supervision. The headmasters who have conducted classroom observations to directly assess the performance of the teacher must make a face-to-face agreement with the teacher as a follow-up step to inform the results of the teacher performance assessment for the improvement and development of their performance to be good or even very good. A very strategic follow-up of class observations is by conducting individual conversations, building teaching commitment and finding the best solutions for class improvement and development through meetings, workshops, individual or group activities. This means that the headmasters have conducted academic supervision. The results of the preliminary survey show that the headmaster only incidentally conducts simple individual meetings or talks with the teacher in carrying out the performance assessment follow-up. The discovery of an effective model of academic supervision through the application of Attachments, namely Grow me please $\mathrm{Ng}$ Pak Tee ${ }^{9}$ and Komariah ${ }^{1}$ is a meaningful development of the technique and method of academic supervision which is a collective and collaborative activity between the headmaster and the teacher. This model is then studied carefully and some adjustments are made to the conditions of supervisors and teachers in Indonesia.

The difficulty of the training instructors in implementing a concept into operational activities with the right steps to be carried out by the training participants, is the main reason in establishing training techniques with direct assistance, such as the used of common concept for headmaster training with the "grow me please" model. The approach of attachment theory is the basis for consideration of the establishment of assistance techniques in implementing a model and this inspires action for the headmasters in applying the grow me please model for teachers in their academic supervision. Through this approach, the headmasters believe that they have to plunge in facilitating and guiding until the activity to improve and develop the learning process is carried out. ${ }^{1011}$

This research develops the operational steps of the grow me model by adding "please" in front of it, and become "grow me please". It is a mentoring philosophy which means, "please develop me". That is a request from the teachers to be facilitated and assisted for a problem that requires clinical-collaborative solutions. "Grow me please", a model of assistance with procedures, sets the Goals first before identifying the existing empirical reality as the Reality faced by the teachers and headmasters. After the reality is well identified, Options or program choices that are agreed upon to be done are displayed. After that, thinking about and discussing the description of the steps for each choice which will be taken next as What next. The clarity of programs and activities must be monitored and evaluated as Monitoring and Evaluation. Grow Me is operationally carried out with an emphatic request in the philosophy of please, namely P as a PLC (Professional Learning Community), $\mathrm{L}$ as a Learning Organization, $\mathrm{E}$ as Empathy, SE as Smart Evaluation (specific, measurable, achievable, realistic, timebound).

The reliability of this model is tested in an effort to carry out academic supervision to fix and improve teacher professionalism on an ongoing basis.

\section{Research Methods}

This study used the Design Based Development Research (DBDR) method adapted from Amiel and Reeves $^{12}$. The ultimate goal of design-based research was to build stronger relationships between educational research and real-world problems (the practice of academic supervision by headmasters to teachers). Emphasis was placed on the iterative research process that not only evaluated products or innovative interventions but also systematically tried to perfect the model by producing principles of academic supervision design that could be applied effectively by both parties, the headmasters and teachers. The stages passed were (1) Analysis of practical problems by researchers and practitioners in a collaboration; (2) development of design models based on the existing theories; (3) Testing and refining the model in practice through an iterative cycle; (4) Reflection to produce the principles of model implementation. They are schematically visualized in Figure 1. The location of the research and development was in the training and education program for the headmasters and supervisors in Bogor Regency and the Collective Activities of Teachers and Headmasters in Pangandaran District.

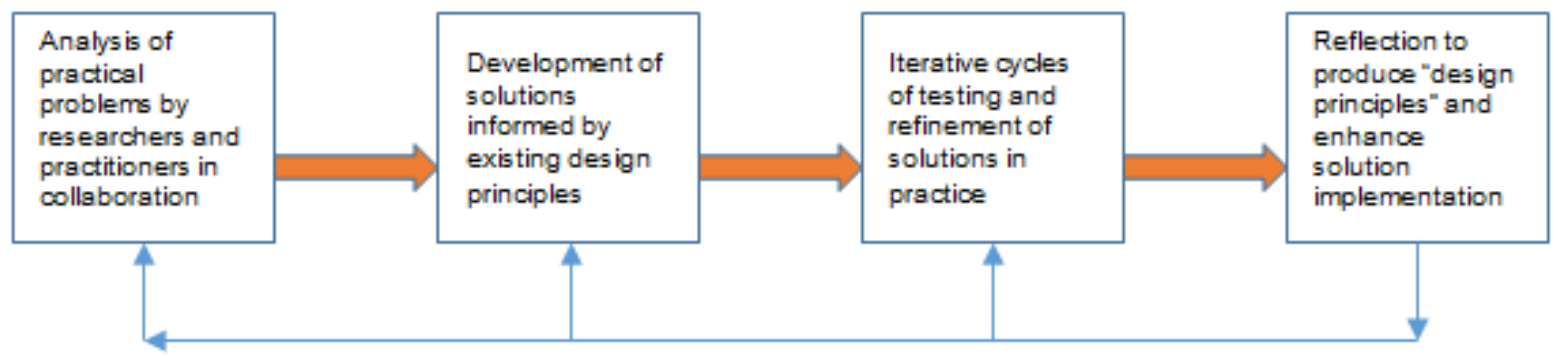

Sources: Amiel, T. \& Reeves, T.C. (2008).

Figure 1. Flow Chart of the Research 


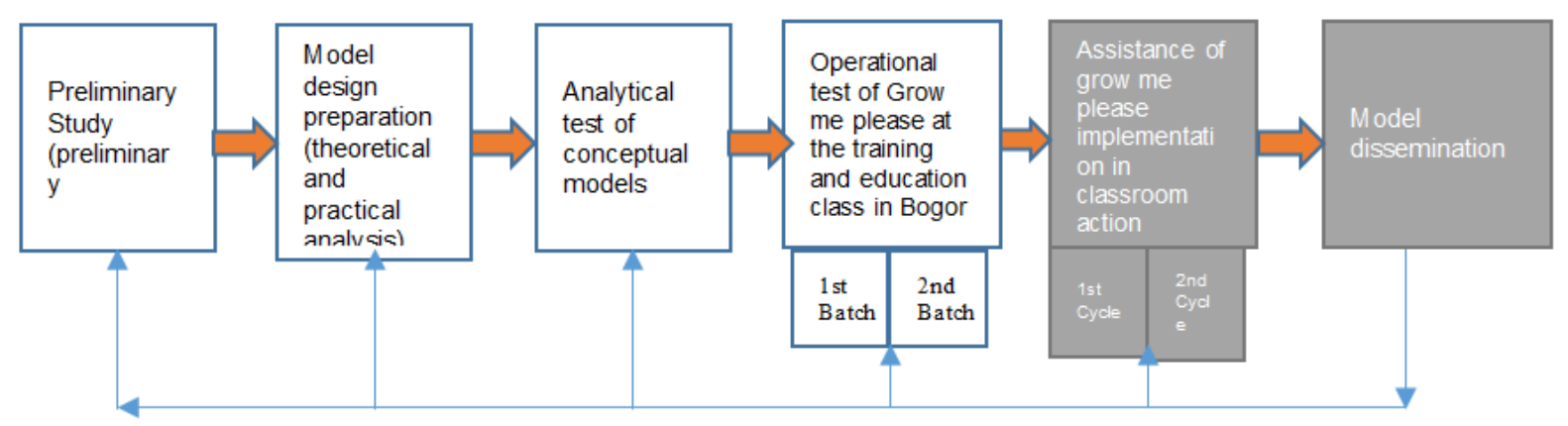

Figure 2. Operational Steps of the Research

Data were obtained through in-depth interviews, FGD (focus group discussions), document studies, observations, questionnaires and performance testing of the implementation academic supervision of grow me please. The interview and FGD guidelines were used as the instruments to capture initial problems, developing concepts and best practices carried out in the implementation of academic supervision between the headmasters and teachers. The Observation Guidelines used the implementation instrument of grow me please to activities during the operational testing process and implementation of assistance. Questionnaires and performance evaluations were used at the operational testing stage and the application of the model assistance. The grow me questionnaire was developed from the results of the research whose theory was adapted from $\mathrm{Ng}$ Pak $\mathrm{Tee}^{9}$ and the Please was from the results of Komariah ${ }^{1}$ research and integrated into grow me please as a model that used the attachment theory approach.

Operationally, this research took the modified steps in the initial stages of preliminary research and design preparation by the team and in the implementation test which used the action research model in each cycle. The following were the operational steps of the research: (1) preliminary study; (2) preparation of grow me please design models; (3) analytical tests of conceptual models by academic supervision experts and FGDs with supervisors, headmasters and associations of supervisors as well as associations of undergraduate education administration and education administration study programs; (4) operational test of substance of grow me please along with the improvement of the implementation principle of the model to the headmasters who were currently in the training program; (5) implementation test of the model using the action research approach in the two cycles of classroom action research mentoring by the headmasters to the teachers; and (6) dissemination of results. This article only reported the operational test of grow me please on the headmaster's training and education program, while the description of the implementation assistance would be presented in other articles. They are schematically visualized in Figure 2, the black highlighted text did not become part of the article reported. The location of research and development was in the training and education program of the headmasters in Bogor Regency.

\section{Results and Discussion}

\subsection{Description of Academic Supervision in Professional Teacher Development}

Some important points as the results of research and development are as follows. (1) The results of the preliminary study found that the implementation of academic supervision by implementing the grow me for teachers for facilitating and assisting the classroom action research have not been implemented, the implementation procedures were still improvised by each headmaster and even to be left to the supervisor or the teachers looking for themselves. Academic supervision was carried out on teacher performance evaluation and was limited to facilitating the implementation of teacher performance assessments. The implementations of academic supervision carried out by the headmasters are as follows: (1) Planning an academic supervision program, (2) Carrying out academic supervision, (3) Following up on academic supervision results. Planning an academic supervision program included identifying problems faced by teachers in implementing learning process, determining academic supervision goals and preparing supervision instruments. Carrying out the supervision program included the implementation of the following activities: carrying out monitoring activities of the learning process and conducting reflection. Following up on the results of academic supervision by facilitating teachers in planning the follow-up and implementing coaching and development for the teachers. Academic supervision carried out by the headmasters for continuous professional development did not enter specifically in the program planning which was arranged in its entirety, but became part of the follow-up of academic supervision in the part of carrying out coaching and development.

Carrying out coaching and development for teachers was still rhetorical by instructing teachers to maintain motivation, enthusiasm, commitment and loyalty in teaching and instructing teachers to participate in professional development activities such as KKG (Teacher Working Group), Seminars, Training, etc. Whereas, the 
implementation of academic supervision related to continuous professional development by the teachers has not been touched properly. Specifically, the headmasters have not carried out special academic supervision for continuous professional development assistance, especially by implementing the grow me please model.

Effective supervision became a quality assurance tool that helped teachers to learn the daily tasks in schools in order to use their knowledge and abilities to provide better service to students, school community and try to make the school became a more effective learning place. Supervision activities were included in teacher development activities that could improve professional abilities, including efforts to develop themselves and develop continuous professionalism such as attending training and education program, seminars, research, preparing learning material and so on. ${ }^{13-15}$

\subsection{Description of Grow me please Model in Teacher Professional Development}

Philosophically, grow me please meant a guidance, with grassroots requests in this case supervisees who hoped to be developed, assisted in their careers, assisted in taking professional steps relevant to current legislation and progress. Sociologically, Grow Me Please was a form of care and fair sharing to solve problems with clear actions that could develop professional teacher's careers. Sharing of knowledge was carried out in a profession as a professional learning community that built a school as a true learning organization where 4 group (supervisors, headmasters, teachers, researchers) gathered to gain knowledge, shared experiences and solved problems collaboratively.

The step of grow me please as a result of the theoretical review, discussions in the FGD (Focus Group Discussion) and interviews with supervisors and headmasters and teachers about implementing appropriate academic supervision for continuous professional development, especially in classroom action research (CAR) are as follows:

\section{A. Description of GROW ME}

\section{Goals (G)}

The first step in implementing grow me in academic supervision both in the mesoscale (strategic program) and microscale (operational) was to set the goals. In addition to become the target of performance, goals also became a measure of success or failure of academic supervision performance in accordance with the program planning that has been set. An academic supervision program showed its function systematically if the goals have been set first. The function of goal setting in grow me was realized effectively through the involvement of teachers as a form of collaboration in planning academic supervision programs. The determination of goals that was carried out collaboratively, increased commitment and shared responsibility to achieve it and allowed mutual reminders to be implemented effectively and if there are shortcomings, they would be reviewed or evaluated together for the improvement. ${ }^{16}$

The goals set out in the academic supervision referred to the school's vision and mission and the continuous strategic program of professional development for teachers that was set in accordance with Regulation of the Minister of Administrative and Bureaucratic Reform No. 16 Year 2009 concerning Teacher's Functional Position and Credit Score $^{17}$. The determination of long-term (long-term goals), mid-term (intermediate goals), as well as short-term academic supervision goals (short-term goals) should be specified, measured, achieved, relevant and have a deadline. The headmasters and teachers agreed on the goals of the academic supervision for continuous professional development in accordance with the four-year promotion for the long-term as well as annual and per semester for operational purposes.

\section{Reality (R)}

After setting the supervision goals, the headmasters and teachers identified the reality as a reality faced to achieve the goal. When talking about reality, the supervisors carried out professional dialogues on career advancement of teachers and led conversations towards finding the problems faced by teachers, realities that hinder the smooth development of teacher professionalism and the possibilities for the future to be achieved. The supervisees had to find some positive and negative facts that could encourage or hinder their goal of becoming professional teachers. The supervisors facilitated the conversation about the trigger and sparked inspiration. All the facts that were discovered by the teacher themselves were realized as their potentials and problems which had to be solved by their own capacity as professional teachers. The supervisors were great communicators who were able to direct the conversation towards professional dialogue concerning quality assurance. Based on professional dialogue which conducted by supervisors and teachers, it showed the facts that teachers still lack in several ways, such as the understanding in using various learning media, the application of contemporary learning methods, developing innovative student worksheets, diversity of assessment patterns of student work in accordance with materials and objectives learning, covering and developing teaching materials, teaching skills practice and in the end teachers cannot conduct classroom action research. This happens because of the confusion by the teachers in determining the method of its implementation, so they cannot compile research reports according to the rules of scientific writing and cannot write articles to be published in scientific journals based on the results of their class research.

\section{Options (O)}

The discussion found the realities faced by teachers in 
developing their careers, followed by alternatives/choices that would be a solution for career development. The supervisors asked the supervisees/teachers to ask themselves and recall the various stored knowledge to find thoughtful theoretical, strategic and operational ways that can bridge the reality and goals. When there was a dead-end conversation because the supervisees did not find a way, the supervisors could provide a clue and supervisees could continue to find the solutions by themselves. Based on the results of the study, the options found by the teachers that were facilitated in the professional dialogue between the headmasters and the teachers, were improving the classroom atmosphere by applying new methods; relevant media; follow-up assessment; preparing student worksheets to assist the learning process of the students; making plans for implementing real learning and in accordance with the material, methods and tools/media; developing more active and creative learning scenarios; learning about the mechanism for implementing class actions; conducting classroom action research; reporting classroom action research activities; compiling scientific articles on classroom action research.

\section{What Next (W)}

Set a plan for more detailed for the results from the analysis of the needs of the teacher according to the performance self-evaluation that has been done. What next explained more about 4WH (What, Why, Who, Where, When, How). This was an operational plan of solutions found by the teachers and headmasters in the improvement of the quality of lessons and education. What Next (W), which was a continuation of the options found by teachers and headmasters in their professional dialogue, created various agreements to fix and improve the quality of performance. What next that was found from the results of the study was carrying out inhouse training, attending training, and attending teacher's collective activities at the PLC.

Field findings indicated that what next for the teachers was still not diverse and in accordance with the existing theories and legislation. Continuous professional development that was quite popular among teachers and became one of the elements of career advancement in accordance with the Regulation of the Minister of Administrative and Bureaucratic Reform No. 16 Year 2009 concerning Teacher's Functional Position and Credit Score ${ }^{17}$ was not comprehensively understood. Continuous Professional Development (PKB) activities to develop the teacher competencies, maintain, improve, and expand the knowledge and skills to carry out professional learning processes have not been fully implemented gradually, sustainably and in accordance with the needs so that the teachers did not know much about the activities that could be followed and created by the school.

\section{Monitoring and Evaluation (ME)}

Plans that have been set and used as guidelines for the implementation of the principal's clinical supervision program for teachers required serious monitoring and evaluation. Monitoring was the process of systematic and continuous gathering and analysis of information (which was previously determined by indicators of success and failure about academic supervision programs so that corrective actions could be taken to further improve the supervision program. Academic supervision monitoring indicators covered the essence of academic supervision activities (starting from the phases of preparation, agreement, classroom observation and dialog about the quality assurance of an education) and target set in the planning of academic supervision programs such as promotion, improvement of the learning culture, or classroom problem solving. Academic supervision required monitoring to ensure that the activities remained on track (in accordance with the program guidelines and planning). It also provided information as feedback to the teachers and headmasters when there were obstacles and irregularities, as well as becoming an input in conducting evaluations. Evaluation is the process of assessing the goals achievement and disclosing the academic supervision performance problems to provide feedback from improving the quality of the learning and education.

\section{B. The Description of PLEASE}

Analytical testing of the grow me please concept was carried out by involving the education supervision experts and FGDs with the headmasters, supervisors and teachers. The analytical results of the education supervision experts showed that the overall model and product prototype produced were good and could be followed up through the operational test. Testing the validity of the substance, especially module products, was conducted through FGDs with working groups of the school supervisors and working groups of headmasters and teachers. The FGDs results showed that the overall substance of the material was correct in the process of implementing continuous professional development assistance so that it could be followed up through the operational testing. Operational testing of growme was carried out by PLEASE. The explanation about please is as follows:

Professional Learning Community (P) was a study group of the headmasters and teachers who were the members of the teacher working group (KKG)/ Principal Consultative Work (MKKS). For the school level, a professional team of school teachers could be created. Learning Organization / LO (L), the headmasters and teachers have to realize and revive schools as the Learning Organizations. Empathy (E), the implementation of activities was based on mutual empathy rather than competition. Assurance (A), guarantee PKB activities had clear goals, structure, planning, monitoring and evaluation. Smart Evaluation (SE), PKB program evaluation has SMART criteria such as specific, measurable, achievable, realistic and timebound. The following table summarizes the description of the grow me please. 
Table 1. Description of the Grow me Please Model in Improving Academic Supervision Performance of the Headmasters

\begin{tabular}{|c|c|c|}
\hline No & Component & Description \\
\hline \multicolumn{3}{|c|}{ GROW ME PLEASE (Goals-Reality-Options-Whatnext-Monitoring-Evaluation-PLC-LO-Empathy-Assurance-SMART Evaluation) } \\
\hline 1. & Goals & Determine the goals to be achieved by the teacher from the Continuous Professional Development \\
\hline 2 & Reality & Identify the realities that exist in the school and outside the school \\
\hline 3 & Options & Display choices of activities to be taken for continuous professional development \\
\hline 4 & What next & Set strategic plans and steps as well as its operational plans \\
\hline 5 & Monitoring & create instruments to measure the effectiveness of activities and for the program feedback \\
\hline 6 & Evaluation & $\begin{array}{l}\text { Determine whether the academic supervision is good to be carried out and making a positive } \\
\text { contribution in improving the learning or the academic supervision must be reviewed for } \\
\text { improvements and even changed. }\end{array}$ \\
\hline 7 & $\begin{array}{l}\text { PLC (Professional Learning } \\
\text { Community) }\end{array}$ & $\begin{array}{l}\text { Grow me is a technique taught and implemented in the KKG/ Teacher Education Consensus Points } \\
\text { (MGMP) as a PLC (professional learning community) that always shares knowledge that is care, fair } \\
\text { and aware. }\end{array}$ \\
\hline 8 & Learning Organization & $\begin{array}{l}\text { PLC in the school must show itself as a Learning Organization that carries out a mission to make the } \\
\text { essence of learning and education become more meaningful as an effort to build an educated } \\
\text { mentality. }\end{array}$ \\
\hline 9 & Empathy & $\begin{array}{l}\text { Feel the problem of non-professionalism in working as a problem for everyone and try to help one } \\
\text { another as well as to learn from each other }\end{array}$ \\
\hline 10 & SMART-Evaluation & Program evaluation using specific, measurable, achievable, realistic and timebound criteria \\
\hline
\end{tabular}

"Grow me please" was a form of coaching conducted by the headmasters to facilitate and assist teachers in carrying out their professional development activities and became one of the potential ways to develop schools. This would not occur automatically, the headmasters needed to build a supportive system and set a good example. GROW ME, which has been popularized by $\mathrm{Ng}$ Pak Tee, was a coaching model oriented to human development. The headmasters as a coach would help the learners achieve their goals. Grow Me as a mentoring model has the main steps in accordance to the letter arrangement, namely $\mathrm{G}$ as goals, $\mathrm{R}$ as Reality, $\mathrm{O}$ as Options, $\mathrm{W}$ as What next, $\mathrm{M}$ as Monitoring and $\mathrm{E}$ as Evaluation. ${ }^{18}$

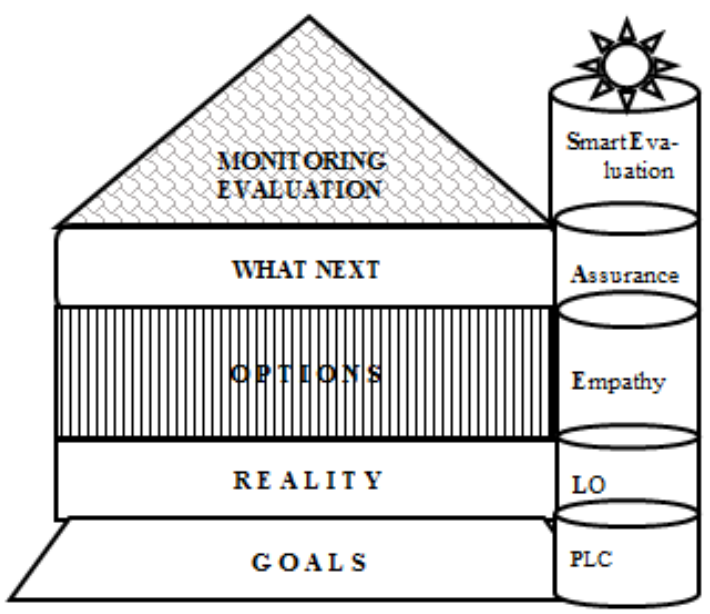

Figure 3. House of GROWME PLEASE

\section{Operational Testing of Grow Me Model}

The grow me please model that was the result of a literature study, in-depth interviews with headmasters, teachers, and supervisors and lecturers in the administration/management department of education, observation of headmasters' academic supervision procedures/practices for teachers and FGDs was then tested for its reliability with operational testing that was carried out cyclically through the main stages of planning, implementation, observation and reflection. The operational testing consisted of two cycles. The first cycle was the Scientific Publication (PI) material and the second cycle was the Classroom Action Research (CAR) material. Each cycle was carried out during 6 hours of lessons starting with the pretest, an explanation of the scientific publication material (cycle 1), CAR (cycle 2), explanation of the grow me technique, simulation of grow me please for each material and posttest. Data on the implementation of "grow me please" and the understanding of PI and CAR in each cycle were taken using an observation sheet on learning that used Grow Me Please and posttest assessment of the understanding of PI and CAR of the training participants. The observations on the implementation of learning by using grow me please covered the mastery aspects of the grow me please process in overall learning and the training participants' responses to the grow me please model in implementing academic supervision. The assessment or post-test not only contained the ability in PI and CAR by using the grow me please implementation step. The CAR and PI standard set was a score of 75 . The conclusions of each cycle showed the achievements that exceed the standard. The results of each cycle showed its consistency in the $1^{\text {st }}$ and $2^{\text {nd }}$ cycles. The increase in the $2^{\text {nd }}$ cycle was caused by a reflection of the $1^{\text {st }}$ learning cycle. The research did not compare between pretest and posttest but the standards was set first and this standard were used as a Learning Mastery Standard. The following is the achievement of the learning which outcomes of the headmaster's training by applying grow me please in the scientific publications and innovative works material. 


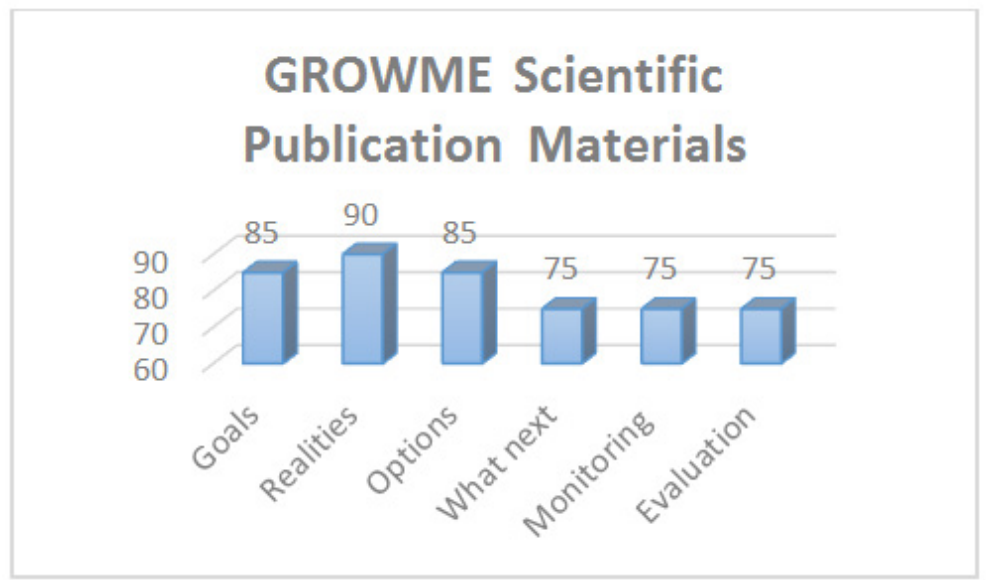

Graph 1. $1^{\text {st }}$ Cycle of Grow me

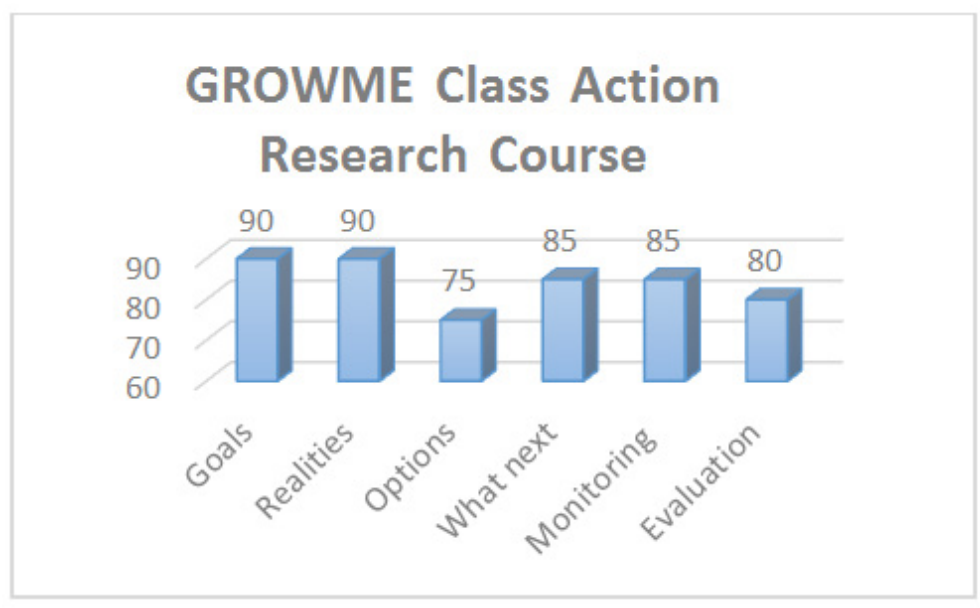

Graph 2. $2^{\text {nd }}$ Cycle of Grow me

In Graph 1, the grow me concept of scientific publications have been very ideal to mention issues related to scientific publications, have been good at setting goals and choosing activities but were still standard on what must be done, determining instruments of monitoring and evaluation that would be conducted. Whereas in graph 2 , setting goals and stating the various realities that occurred in learning process were already very good, in the actions selection section that was still standard required keywords from the supervisor. However, after the action was determined, the things to be done, the monitoring instrument that must be prepared and evaluation that would be carried out were found by supervisee. The two cycles showed consistency in the achievement of results that exceeds the score of 75 as the learning mastery standard of grow me as a model of guidance or scientific publication and CAR as the substance that was the focus of the study. The following is a graph of the consistency of the achievement of material substance by applying the grow me model.

The Consistency of GROWME achievements $1^{\text {st }}$ and $2^{\text {nd }}$ Cycle

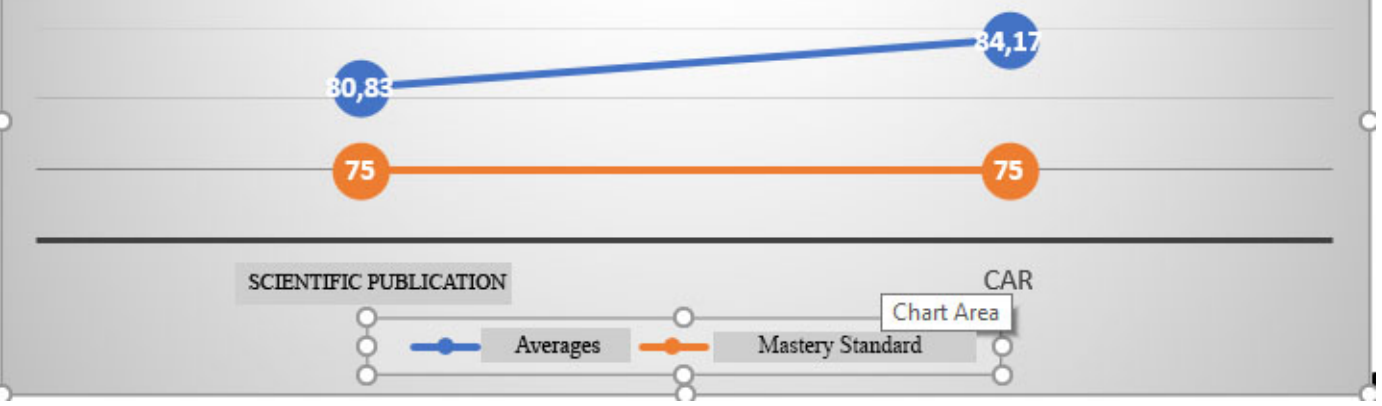

Graph 3. Consistency of Growme achievements, $1^{\text {st }}$ and $2^{\text {nd }}$ cycle 
Graph 3 is the consistency of the grow me model that has achieved the results by exceeding the standards of 75 in each cycle. There was an increase in the average, presumably because of reflection carried out in the $1^{\text {st }}$ cycle made steps improvements in the $2^{\text {nd }}$ cycle.

\section{The Modifications of Please in Implementing Grow Me}

The implementation of growme in academic supervision was more effective in a conducive social situation which called "please". Schools should be seen as a gathering place for professional communities that concerned with quality improvement and development. The concept of the school should be returned as the best place to learn by absorbing and developing the principles of learning organizations. As a Professional Learning Community that carried out the mission of a learning organization, schools in carrying out academic supervisions should be based on a high sense of empathy. Although it was built on a high sense of empathy, it did not mean that schools, especially the implementation of academic supervision, were transformed into a transactional approach. It should have a high guarantee of quality as the main task of the supervisor's role. As a step that had quality assurance, the evaluation standard developed was smart evaluation.

Unlike Grow me, this "Please" framework was still conceptual, has not been tested for its reliability and validity. However, the application of grow me with modification please has become an alternative model for conducting professional coaching conducted by supervisors. The training participants' responses to the learning by implementing grow me practice in understanding PI and CAR were very good and in a high category. Moreover, they strongly suggested developing an applicable conceptual framework for the concept of please as the media. The training participants were very fond of this model. It was because they could collaborate directly with the teachers and able to set clear steps in mentoring, besides adding knowledge to be applied. They stated that the grow me please model could really be used as a model that guided the operational work of supervising teachers, especially in the CAR mentoring practice. This showed that the grow me please model was the conceptual framework used by the headmasters as work patterns for conducting academic supervision. This was in accordance with the definition of the model, i.e. the conceptual framework that explain the path of a research and ground it firmly in theoritical construct. ${ }^{20}$ Facilitation and mentoring of CAR with the strategy of "grow me please" was a form of coaching with attachment theory that made the headmasters and teachers collaborate actively. In this strategy, the headmasters became a good coach, who had a strong emotional bond to guide teachers to find and solve problems in accordance with their needs and abilities. ${ }^{10} 19$

The headmasters had the responsibility to develop the teachers as the spearhead of effective learning and improve its performance as a contribution in achieving the school's vision. With those varieties of problems, the teachers had the desire to improve and develop and the headmasters should come forward to be a claimant for solving teacher problems in learning that required a direct explanation rather than discussion discourse. Usually, teachers faced problems in conducting the CAR in addition to several other scientific publication activities. As a concept, it is clear that teachers needed examples for the first time before they could run it by themselves with full confidence. This was where the method of "grow me please" became a form of innovation of the headmasters in facilitating and mentoring the CAR and other teacher professional development activities with a strong emotional bond between the headmasters and teachers. ${ }^{10}$

\section{Conclusions}

Grow me please in the practice of academic supervision was the mainstay of the headmasters in the implementation of continuous professional development. Through grow me please, the headmasters had a mentoring guidance with realistic-systematic steps that allowed programs to emerge from the teachers (bottom up) rather than from the headmasters (top down policy). Grow me please enabled collaborative agreement between the headmasters and teachers in carrying out continuous professional development. The goal was the objectives agreed upon between the headmasters and teachers that was defined based on the reality. The reality that has been clearly identified became the main reason for determining the alternative choice of the programs and each program choice was further developed in a feasible manner. The programs as options to achieve objectives were monitored and evaluated so that they could run effectively and efficiently.

Grow me please was carried out more effectively in a media of professionalism, namely the Professional learning community (PLC) whose enthusiasm followed a learning organization/LO paradigm and based on the emphatic principles (impressive emphatic) and upholded the quality of learning as its guarantee (assurance) through the Smart Evaluation (specific, measurable, achievable, realistic and time bound). Grow me please, not only could be applied for continuous professional development but also could to provide further steps on teacher performance assessment. In other words, grow me please could be applied by the headmasters in providing guidance and development of the professionalism and career of the teacher as part of the steps in academic supervision work.

\section{REFERENCES}

[1] Komariah. A, Soemarto., Dedy A.K (2018). Professional 
Learning Community Based Academic Supervision Model In Improving Teacher Performance. Bandung:LPPM UPI.

[2] Ugurlu, C. T. (2014). Current Problems in Terms of Supervision Process of School Principals' Views. Hacettepe Universitesi Egitim Fakultesi Dergisi-Hacettepe University Journal of Education, 29(3), 184-196.

[3] Glickman, C.D., S.P. Gordon and J.M. Ross-Gordon, (2009) Super vision and instructional leadership: A developmental approach. 7th Edn., New York: Pearson Education Inc.

[4] Harrison, C. and J. Killion, (2007). Ten roles for teacher leaders. Educational Leadership, 65(1): 74-77. View at Google Scholar

[5] Leithwood, Kenneth. \& Day, Christopher. (2007). Successful Principal Leadership in Times of Change.New York: Springer

[6] Marzano, R. J. \& Waters, J. T. (2006). School leadership that works: The effect of superintendent leadership on student achievement. Denver, CO: Mid-continent Research for Education and Learning (available at www.mcrel.org).

[7] Bitterová, Miriam; Hašková, Alena; Pisoová, Maria. (2014). School Leader`s Competencies in Management Area. Social and Behavioral Sciences 149 (2014) $114-118$

[8] Bredeson, P. V., \& Johansson, O. (2000). The School Principal's Role In Teacher Professional Development. Journal of In-Service Education, 26(2), 385-401. https://doi.org/10.1080/13674580000200114

[9] Ng, Pak Tee. (2005). Grow Me! Coaching For Schools. Singapore: Pearsons/Prentice Hall

[10] Bergin, C., \& Bergin, D. (2009). Attachment in the Classroom. Educational Psychology Review, 21(2), 141170. https://doi.org/10.1007/s10648-009-9104-0

[11] Ainsworth, M. D. S. (1979). Infant-mother Attachment. The American Psychologist, 34(10), 932-937. doi:10.1037/0003-066X.34.10.932.

[12] Amiel, T., \& Reeves, T. C. (2008). Design-Based Research and Educational Technology: Rethinking Technology and the Research Agenda. Educational Technology \& Society, 11 (4), 29-40.

[13] Sergiovanni, T.J. and R. Starratt, (2007). Supervision: A Redefinition. 9th Edn., New York: MacGraw-Hill.

[14] Glickman,C.D Gordon (2002). Learning Leadership : How to help Teachers Succeed.United State. Association for Supervision and Curriculum Development.

[15] Mudawali and Mudzofir. (2017). Relationship between Instructional Supervision and Professional Development: Perceptions of Secondary School Teachers and Madrasah Tsanawiyah (Islamic Secondary School) Teachers in Lhokseumawe, Aceh, Indonesia. University of Tampere School of Education.

[16] Griffin, R. W., \& Ebert, R. J. (2006). Bisnis. Jakarta: Erlangga

[17] Permenegpan RB N0 16 Tahun 2009 Tentang Jabatan Fungsional Guru dan Angka Kreditnya

[18] Whitemore, Sir John; Kauffman, Carol; David, Susan A
(2013). "GROW grows up: from winning the game to pursuing transpersonal goals". In David, Susan A, Clutterbuck, David; Megginson, David. Beyond goals: effective strategies for coaching and mentoring. Farnham, Surrey: Gower Publishing Limited. pp. 245260. ISBN 9781409418511. OCLC 828416668.

[19] Pistole, M. Carole., Watkins, C. Edgard. (1995). Attachment Theory, Counseling Process, and Supervision. The Counseling Psychologist 23(3):457-478

[20] Adom, D., E.K.Hussein and Joue, A.A. (2018). Theoritical and Conceptual Framework: Mandatory Ingredients of a Quality Research. International Journa f Scientific Research7 (1): 438-441 